\title{
Status Badan Hukum Usaha Ekonomi Desa/Kelurahan Simpan Pinjam (UED/K-SP) di Kecamatan Bengkalis
}

\author{
Soekardi,Yalid* \\ Universitas Lancang Kuning, \\ Jalan Yos Sudarso Km 8 Rumbai, Pekanbaru, Indonesia \\ e-mail: yalid@unilak.ac.id
}

\begin{abstract}
Abstrak
Rumusan masalah dalam penelitian ini ada 3 (tiga). Pertama, Bagaimanakah pendirian badan hukum UED/K-SP di Kecamatan Bengkalis? Kedua, bagaimanakah hambatan pendirian badan hukum UED/K-SP di Kecamatan Bengkalis? Ketiga, bagaimanakah upaya mengatasi hambatan pendirian badan hukum UED/K-SP di Kecamatan Bengkalis? Sejalan dengan rumusan masalah tersebut maka tujuan penelitian ini pun ada 3 (tiga). Pertama, untuk menjelaskan pendirian badan hukum UED/K-SP di Kecamatan Bengkalis. Kedua,untuk menjelaskan hambatan pendirian badan hukum UED/K-SP di Kecamatan Bengkalis. Ketiga, untuk menjelaskan upaya mengatasi hambatan pendirian badan hukum UED/K-SP di Kecamatan Bengkalis. Jenis penelitianadalah penelitian hukum empiris untukmeninjau efektivitas berlakunya hukum. Lokasi penelitian di Kecamatan Bengkalis Kampar Kiri Hulu. Pertimbangan penulis memilih lokasi ini karena dari legalitas pembentukan UED/K-SP yang merupakan unit usaha BUMDesa di Kecamatan Bengkalis ditinjau dari perspektif hukum bertolak belakang dengan Undang-Undang Nomor 1 Tahun 2013 tentang Lembaga Keuangan Mikro (LKM).Hasil penelitian ini dapat dijelaskan pendirian badan hukum UED/K-SP di Kecamatan Bengkalis haruslah berbentuk badan hukum sesuai amanat Pasal 4 huruf a Undang-Undang Nomor 1 Tahun 2013 jo Pasal 8 Permendes PDTT Nomor 4 Tahun 2015. Hasil penelitian ini dapat diketahui tidak ada satupun UED-SP di Kecamatan Bengkalis yang sudah memenuhi persyaratan LKM dan berbadan hukum. Hambatan pendirian badan hukum UED/K-SP di Kecamatan Bengkalis dari hasil penelitian ini jawaban yang relevan hanyalah terkait peralihan aset, sedangkan jawaban selebihnya dari sampel penelitian tidak ada relevansinya dengan hambatan pendirian badan hukum UED/K-SP. Upaya mengatasi hambatan pendirian badan hukum UED/K-SP di Kecamatan Bengkalis tidak ada rencana dan tindakan konkrit untuk mengatasi hambatan dimaksud. Hal ini disebabkan karena seluruh sampel penelitian ini seluruhnya tidak memahami pendirian badan hukum UED/K-SP.
\end{abstract}

Kata Kunci: Status Badan Hukum, UED/K-SP, Kecamatan Bengkalis Abstract 
There are 3 (three) problems in this research. First, how is the UED / K-SP legal entity established in Bengkalis District? Second, how are the obstacles in establishing a UED / K-SP legal entity in Bengkalis District? Third, how is the effort to overcome the obstacles in establishing UED / K-SP legal entities in Bengkalis District? In line with the formulation of the problem, the objectives of this study are 3 (three). First, to explain the establishment of a UED / K-SP legal entity in Bengkalis District. Second, to explain the obstacles to establishing a UED / K-SP legal entity in Bengkalis District. Third, to explain the efforts to overcome the obstacles in establishing UED / K-SP legal entities in Bengkalis District. This type of research is empirical legal research to review the effectiveness of law enforcement. Research location in Bengkalis District, Kampar Kiri Hulu. The author's consideration of choosing this location is because of the legality of the formation of UED / K-SP which is a BUMDesa business unit in Bengkalis District in terms of legal perspective contrary to Law Number 1 of 2013 concerning Microfinance Institutions (MFIs). The results of this study can be explained by the establishment of a UED / K-SP legal entity in Bengkalis District must be in the form of a legal entity according to the mandate of Article 4 letter a of Law Number 1 of 2013 in conjunction with Article 8 of the PDTT Permendes Number 4 of 2015. The results of this study can be known to be absent one UED$S P$ in Bengkalis District has fulfilled the LKM requirements and is a legal entity. Barriers to the establishment of a UED / K-SP legal entity in Bengkalis District from the results of this study are relevant answers only related to the transfer of assets, while the rest of the research sample has no relevance to the obstacles in establishing a UED / K-SP legal entity. Efforts to overcome the obstacles in establishing UED / K-SP legal entities in Bengkalis District have no concrete plans and actions to overcome these obstacles. This is because all of the research samples do not fully understand the establishment of UED / K-SP legal entities.

\section{Keywords: Legal Entity Status, UED / K-SP, Bengkalis District}

\section{Pendahuluan}

Saat ini tersedia banyak lembaga keuangan yang dapat memberikan pinjaman dana misalnya pasar modal, bank, pegadaian, koperasi dan sebagainya. Namun, tidak semua pelaku usaha dapat mengaksespinjaman dana tersebut,disebabkan persyaratan dan ketentuan yang tidak mudah dipenuhi oleh pihak yang membutuhkan dana.

Salah satu lembaga pembiayaan, sepertibank cukup dikenal masyarakat luas. Akan tetapi, dalam praktiknya belum mampu memenuhi berbagai kebutuhan 
masyarakat, khususnya dalam bidang ekonomi dan usaha. Kesulitan masyarakat mengakses dana dari bank disebabkan jangkauan penyebaran kredit bank yang belum merata, keharusan bank melaksanakan prinsip kehati-hatian, kemudian kewajiban debitur untuk menyerahkan jaminan sesuai besaran nilai kredit, serta terbatasnya kemampuan permodalan bank itu sendiri.

Tentu saja, kesulitan mengakses dana bank itu menjadi sebuah halangan bagi pelaku usaha yang kekurangan modal, apalagi bagi masyarakat desa yang terbelakang keadaan ekonominya.Oleh sebab itu, pemerintah pusat dan daerah telah memfasilitasi masyarakat desa dengan membentuk suatu lembaga pembiayaan desa yang disebut Usaha Ekonomi Desa/Kelurahan-Simpan Pinjam (UED/K-SP).

UED/K-SP khususnya di Kecamatan Bengkalis, Kabupaten Bengkalis, Provinsi Riau sudah ada sejak tahun 2011. Secara nasional dasar hukum dibentuknya UED/K-SP berdasarkan Peraturan Menteri Dalam Negeri (Permendagri) Nomor 6 Tahun 1998 tentang UED/K-SP. Pasal 1 huruf $d$ Permendagri Nomor 6 Tahun 1998 mendefinisikan UED/K-SP, yaitu "Usaha Ekonomi Desa-Simpan Pinjam (UED-SP) adalah suatu lembaga yang bergerak di bidang simpan pinjam dan merupakan milik masyarakat desa/kelurahan yang diusahakan serta dikelola oleh masyarakat desa/kelurahan".

UED/K-SP tujuannya untuk menanggulangi kemiskinan di daerah, dengan sasaran utama masyarakat ekonomi kelas bawah yang memiliki bidang usaha sehingga bisa terbebas dari kesenjangan ekonomi, serta sasaran para rentenir. Dengan demikian, kehadiran UED/K-SP di pedesaan/kelurahan, dapat membantu masyarakat kecil/miskin dalam upaya mendapatkan modal usaha dengan persyaratan yang mudah, murah dan cepat dengan tujuan yang nyata, yakni dapat meningkatkan taraf hidup dan kesejahteraan bagi masyarakat.

Kegiatan UED/K-SP berkonsentrasi pada pemberian pinjaman dana usaha pada masyarakat yang membutuhkan modal usaha dan lainnya sebagaimana ditegaskan pada Pasal 5 Permendagri Nomor 6 Tahun 1998. Adapun bunyi Pasal 5 Permendagri sebagai berikut:

a. Memberikan pinjaman uang untuk kegiatan usaha masyarakat desa/kelurahan yang dinilai produktif.

b. Menerima pinjaman uang dari masyarakat desa/kelurahan sebagai anggota UED-SP.

c. Ikut serta memberikan bimbingan dan penyuluhan kepada anggota UED-SP dalam kaitan kegiatan usahanya.

d. Melaksanakan koordinasi dengan lembaga perbankan/perkreditanlainnya dalam pelaksanaan simpan pinjam. 
Untuk di Kecamatan Bengkalis, UED/K-SP dalam memberikan pinjaman dana usaha kepada masyarakat dilaksanakan dalam bentuk perjanjian tertulis. Dari 31 desa/kelurahan telah melaksanakan UED/K-SP sejak tahun 2011 total pengucuran dana telah mencapai Rp 5.000.000.000,00 (lima miliar rupiah) per desa/kelurahan.

Sejak bergulirnya program UED/K-SP di Kecamatan Bengkalis dana yang dikelola semakin berkembang. Bahkan ada UED/K-SP di Kecamatan Bengkalis mengelola dana mencapai Rp 8.000.000.000,00(delapan miliarrupiah) hingga Rp 10.000.000.000,00 (sepuluhmiliar rupiah). ${ }^{1}$ Program UED/K-SP tersebut hingga 2019 tetap berjalan melalui pengelolaan desa/kelurahan.

Pelaksanaan program UED/K-SP tidak lepas dari kendala atau permasalahan. Teknispenyaluran pinjaman kepada masyarakat selaku debiturdibekalidengan dasarperjanjian antara UED/K-SP dengan masyarakat pemanfaat dana (debitur). Dalam setiap perjanjian tersebuttelah ditentukanbahwa debitur akan membayar angsuran setiap bulan kepada pihak pemberi pinjaman (kreditur). Namun, dalam pelaksanaannya tidak semua debitur lancar membayar angsuran tersebut. Hal ini merupakan tantangan dan risiko dalam pemberian kredit /pinjaman tersebut,padahal semestinya tidak ada tunggakan kewajiban. Tunggakan kewajiban diartikan bahwa ada sebagian pinjaman yang telah diberikan kepada debitur/pemanfaat dana mengalami kemacetan pembayarannya. ${ }^{2}$

Permasalahan lainnya terkait legalitas UED/K-SP sendiri, bahwa Lembaga Keuangan Mikro (LKM), seperti Badan Usaha Milik Desa (BUMDesa) yang memiliki unit usaha berbentuk UED/K-SP sama juga posisinya dengan lembaga keuangan lainnya di Indonesia. Akan tetapi, fenomena yang terjadi justru banyak BUMDesa yang belum memiliki izin dari Otoritas Jasa Keuangan (OJK). Kondisi ini, tentunya tidak sejalan dengan amanat Undang-Undang Nomor 1 Tahun 2013 tentang Lembaga Keuangan Mikro (LKM) terutama pada Pasal 4, Bagian Kesatu, terkait pendirian LKM.

Untuk pendirian LKM, Pasal 4 mempertegas jika LKM harus berbadan hukum, permodalan, dan mendapat izin usaha yang tata caranya diatur dalam Undang-Undang Nomor 1 Tahun 2013. Kemudian untuk badan hukum tersebut, diperbolehkan dalam berbentuk koperasi atau perseroan terbatas (PT).

Berkenaan dengan Undang-Undang Nomor 1 Tahun 2013 tersebut, perizinan juga menjadi hal yang paling penting. Karena perizinan merupakan bentuk dari kepastian hukum dalam memenuhi kebutuhan layanan keuangan

${ }^{1}$ http://www.halloriau.com/read-bengkalis-59541-2015-01-29-dana-uedsp-setiap-desa-capairp5-miliar.html, terakhir diakses tanggal 29 Januari 2015.

${ }^{2}$ Budi Hartono, Perlindungan Debitur KPM \& KPR Menghadapi Penagihan Hutang dan Lelang Jaminan oleh Kreditur, (Jakarta: PT Pustaka Utama Grafiti, 2009), hlm. 1. 
terhadap masyarakat miskin dan/atau berpenghasilan rendah. Pasal 9, UndangUndang Nomor 1 Tahun 2013 menyebutkan:

(1) Sebelum menjalankan kegiatan usaha, LKM harus memiliki izin usaha dari Otoritas Jasa Keuangan

(2) Untuk memperoleh izin usaha LKM sebagaimana dimaksud pada ayat (1), harus dipenuhi persyaratan paling sedikit mengenai:

a. Susunan organisasi dan kepengurusan

b. Permodalan

c. Kepemilikan

d. Kelayakan rencana kerja.

Kegiatan lebih lanjut mengenai permodalan sebagaimana dimaksud dalam Pasal 4 huruf b, kepemilikan LKM sebagaimana dimaksud dalam Pasal 8, dan tata cara perizinan usaha sebagaimana dimaksud dalam Pasal 9 diatur dalam Peraturan Otoritas Jasa Keuangan (OJK) terkait.

Merujuk pada Undang-Undang (UU) Nomor 1 Tahun 2013 tentang LKM UED/K-SP yang saat menjadi sebuah LKM yang merupakan unit usaha dari BUMDesa, sejatinya telah memiliki sebuah penyempurnaan yang lebih spesifik di bawah pengelolaan BUMDesa. Sebab, dari sisi kelembagaan BUMDesa merupakan badan usaha yang juga harus tunduk pada perundang-undangan mulai dari tingkat Undang-Undang, Peraturan Daerah (Perda), sampai pada Peraturan Desa.

Untuk tingkat Kabupaten Bengkalis sudah adapedoman pembentukan BUMDesa berdasarkan PerdaKabupaten Bengkalis Nomor 1 Tahun 2014 tentang Tata Cara Pembentukan dan Pengelolaan Badan Usaha Milik Desa.Menurut Perda Kabupaten Bengkalis No. 1 Tahun 2014 peralihan pembentukan UED/SP dari sisi modal haruslah dipisahkan dari kekayaan desa, karena BUMDesa merupakan badan hukum sesuai dengan ketentuan peraturan perundangan. Hal ini dapat dilihat pada ketentuan Pasal 13 yang berbunyi:

(1) Modal BUMDesa berasal dari:

a. Sebagian atau seluruh kekayaan desa yang dipisahkan oleh pemerintah desa;

b. Masyarakat;

c. Pinjaman;

d. bantuan Pemerintah, Pemerintah Provinsi, Pemerintah Kabupaten; dan

e. penyertaan modal pihak lain, atau kerjasama bagi hasil atas dasar saling menguntungkan. 
Sejak Perda Kabupaten Bengkalis tersebut dibuat dalam pengamatan penulis baru ada satu desa yang telah memenuhi syarat pembentukan UED/SP menjadi BUMDesa, yaitu Desa Penebal Kecamatan Bengkalis. Pengamatan sementara pembentukan UED/SP menjadi BUMDesa disebabkan tarik ulur pemisahan kekayaan desa yang harus dituangkan dalam bentuk Peraturan Desa. Sementara, seluruh desa di Kabupaten Bengkalis sudah memiliki UED/SP dan sudah beroperasi melayani kebutuhan modal masyarakat ekonomi mikro. Sejalan dengan itu, maka ini akan menjadi kendala dalam perizinan, pelaksanaan, dan pengawasan disebabkan pendirian UEP/SP belum memenuhi persyaratan badan hukum. Berkaitan dengan keadaan tersebut maka penulis tertarik untuk menelitinya. Penelitian ini belum pernah diteliti sebelumnya, dari tinjauan pustaka meskipun ada penelitian terdahulu, tetapi berbeda substansinya dengan penelitian ini.

Hasil tinjauan pustaka,penulismenemukantulisan Rahmi Puspita Sari dan kawan-kawan. Penelitiannyaberkaitan dengan analisis kinerja sosial dan kinerja keuangan UED-SP Mekar Jaya Desa Bukit Sembilan Kecamatan Bangkinang Kabupaten Kampar. ${ }^{3}$ Namun, penelitiannya bukan penelitian hukum, tetapi berkaitan dengan kinerja sosial dan kinerja keuangan.

Kemudian penelitian Galih Delia berkaitan dengan implementasi kebijakan pengembangan UED-SP menjadi BUMDesa studi di BUMDesa Mekar Sari Desa Rambah Baru Kecamatan Rambah Samo. ${ }^{4}$ Meskipun penelitiannya berkaitan dengan pengembangan UED-SP menjadi BUMDesa, namun bukan penelitian hukum. Penelitian Galih Delia berkaitan dengan isu administrasi kebijakan, bukan mengkaji pelaksanaan norma hukum pendirian UED-SP menjadi BUMDesa.

Terakhir penulis menemukan penelitian yang dilakukan oleh Yulia Risa dan kawan-kawan. Penelitiannya berkaitan dengan mekanisme pendirian Badan Usaha Milik Nagari (BUMNag) di Nagari Cupak, Kecamatan Gunung Talang Kabupaten Solok. ${ }^{5}$ Penelitian Yulia Risa dan kawan-kawan bukan mengkaji pelaksanaan norma hukum pendirian UED-SP menjadi BUMDesa.Dengan

\footnotetext{
${ }^{3}$ Rahmi Puspita Sari, Rosnita, dan Ahmad Rifai, Analisis Kinerja Sosial dan Kinerja Keuangan Lembaga Keuangan Mikro (LKM) Usaha Ekonomi Desa-Simpan Pinjam (UED-SP) Badan Usaha Milik Desa (BUMDes) Mekar Jaya Desa Bukit Sembilan Kecamatan Bangkinang Kabupaten Kampar, Jurnal Online Mahasiswa, Fakultas Pertanian Universitas Riau, Vol. 1, No. 2 Oktober 2019, hlm. 1.

${ }^{4}$ Galih Delia, Implementasi Kebijakan Pengembangan UED-SP Menjadi Bumdes di Kabupaten Rokan Hulu (Studi Kasus Bumdes Mekar Sari Desa Rambah Baru Kecamatan Rambah Samo), Jurnal Online Mahasiswa Fakultas Ilmu Sosial dan Politik Universitas Riau, Vol. 5, Edisi I Januari-Juni 2018, hlm. 14.

${ }^{5}$ Yulia Risa, Engrina Fauzi dan Jelisye Putri Cenery, Peranan Pendirian Badan Usaha Milik Nagari Berdasarkan Undang-Undang Nomor 6 Tahun 2014 tentang Desa dalam Upaya Peningkatan Ekonomi Masyarakat di Nagari Cupak Kecamatan Gunung Talang Kabupaten Solok, Jurnal Ius Constituendum, Vol. 4 No. 2, Oktober 2019, hlm. 195.
} 
demikian, penelitian terdahulu tersebut jelas berbeda dengan substansi penelitian ini, sehingga penelitian inimenarik untuk dibaca karena merupakan sesuatu yang baru.

Adapun permasalahan penelitian ini: Pertama,bagaimanakahpendirian badan hukum UED/K-SP di Kecamatan Bengkalis?Kedua, bagaimanakahhambatan pendirian badan hukum UED/K-SP di Kecamatan Bengkalis?Ketiga bagaimanakah upaya mengatasi hambatan pendirian badan hukum UED/K-SP di Kecamatan Bengkalis?Sejalan dengan permasalahan tersebut maka tujuan penelitian ini untuk menjelaskan dari masing-masing permasalahan tersebut.

\section{Metode Penelitian}

Penelitian merupakan suatu usaha untuk menganalisis serta mengadakan konstruksi secara metodologis, sistematis dan konsisten. Penelitian merupakan sarana yang dipergunakan untuk memperkuat, membina serta mengembangkan ilmu pengetahuan. ${ }^{6}$ Untuk mendukung suksesnya penelitian ini dalam rangka memberikan jawaban atas permasalahan yang telah dirumuskan, maka penulis menentukan metode penelitian sebagai berikut.

1. Jenis dan sifat penelitian

Jenis penelitian ini adalah penelitian hukum empiris, yaitu penelitian yang dilakukan dengan meninjauefektivitas hukum, kepatuhan terhadap aturan hukum, peranan lembaga atau institusi hukum dalam pencegahan hukum, implementasi aturan hukum, pengaruh aturan hukum terhadap masalah sosial tertentu atau sebaliknya, pengaruh masalah sosial tertentu terhadap aturan hukum yang berlaku dalam masyarakat. ${ }^{7}$

2. Lokasi penelitian

Lokasi penelitian di Kecamatan Bengkalis, Kabupaten Bengkalis. Ada sebanyak 31 desa/kelurahan yang melaksanakan program pemberdayaan masyarakat melalui kegiatan UED/K-SP. Adapun alasan penulis mengambil lokasi penelitian ini karena dari legalitas pembentukan UED/K-SP yang merupakan unit usaha BUMDesa di Kecamatan Bengkalis ditinjau dari perspektif hukum bertolak belakang dengan Undang-Undang Nomor 1 Tahun 2013 tentang Lembaga Keuangan Mikro (LKM).

3. Populasi dan sampel

a. Populasi

\footnotetext{
${ }^{6}$ Soerjono Soekanto, Pengantar Penelitian Hukum, (Jakarta: UI Press, 1986), hlm. 3.

${ }^{7}$ Peter Mahmud Marzuki, Penelitian Hukum, (Jakarta: Kencana, 2009), hlm. 87. 
Populasi adalah keseluruhan atau himpunan subjek dengan ciri yang sama. Adapun populasi dalam penelitian ini terdiri dari Kepala Dinas Pemberdayaan Masyarakat dan Desa (DPMD)Kabupaten Bengkalis berjumlah 1 orang, Camat Bengkalis berjumlah 1 orang, Kepala Desa/Kelurahan di Kecamatan Bengkalis berjumlah 31 orang, Ketua/Direktur BUMDesadan Ketua UED/K-Sdi Kecamatan Bengkalis masing-masing berjumlah 31 orang.

b. Sampel

Sampel adalah himpunan bagian atau sebagian dari populasi. Adapun yang diambil menjadi sampel dalam penelitian ini, yaitu Kepala DPMD Kabupaten Bengkalis, dan Camat Bengkalis populasinya masingmasing berjumlah 1 (satu) orang maka secara sensus keseluruhannya ditetapkan menjadi sampel. Kemudian populasi Kepala Desa/Kelurahan, Ketua/Direktur BUMDesa, dan Ketua UED/K-SP di Kecamatan Bengkalis populasinya masing-masing berjumlah 31 (tiga puluh satu) orang maka secara random sampling masing-masing diambil 5 orang menjadi sampel.

Keadaan populasi dan sampel di atas dapat dilihat pada tabel berikut:

Tabel

Populasi dan Sampel

\begin{tabular}{|c|c|c|c|c|}
\hline No. & Jenis Populasi & $\begin{array}{l}\text { Jumlah } \\
\text { Populasi }\end{array}$ & $\begin{array}{l}\text { Jumlah } \\
\text { Sampel }\end{array}$ & $\begin{array}{c}\text { Persentase } \\
(\%)\end{array}$ \\
\hline 1 & $\begin{array}{l}\text { Kepala Dinas } \\
\text { Pemberdayaan } \\
\text { Masyarakat dan } \\
\text { Desa (DPMD) } \\
\text { Kabupaten } \\
\text { Bengkalis }\end{array}$ & 1 orang & 1 orang & 100 \\
\hline 2 & Camat Bengkalis & 1 orang & 1 orang & 100 \\
\hline 3 & $\begin{array}{l}\text { Kepala } \\
\text { Desa/Kelurahan di } \\
\text { Kecamatan } \\
\text { Bengkalis }\end{array}$ & 31 orang & 5 orang & 16 \\
\hline 4 & $\begin{array}{l}\text { Ketua/Direktur } \\
\text { BUMDesa di } \\
\text { Kecamatan } \\
\text { Bengkalis }\end{array}$ & 31 orang & 5 orang & 16 \\
\hline \multirow[t]{2}{*}{5} & $\begin{array}{l}\text { Ketua UED/K-SP di } \\
\text { Kecamatan } \\
\text { Bengkalis }\end{array}$ & 31 orang & 5 orang & 16 \\
\hline & Jumlah & 95 orang & 12 orang & \\
\hline
\end{tabular}


Sumber data: primer diolah tahun 2019

4. Sumber data

Penelitian ini menggunakan 3 (tiga) sumber data terbagi atas:

a. Data primer, yaitu data diperoleh secara langsung dilapangan, melalui teknik observasidan wawancara.

b. Data sekunder, yaitu data diambil dari bahan buku sekunder, dengan cara mencari peraturan perundang-undangan, buku literatur, baik berupa buku teks, jurnal hasil penelitian yang relevan dengan penelitian ini.

c. Data tertier, yaitu yang berfungsi sebagai pendukung data primer dan sekunder yang berupa kamus dan ensiklopedi.

5. Teknik pengumpulan data

a. Observasi

Istilah observasi menurut Kamus Besar Bahasa Indonesia memiliki pengertian mengamati dan meninjau secara cermat dan teliti, yaitu terhadap suatu hal yang menjadi pokok atau objek penelitian, agar peneliti dapat memperoleh data-data dan gambaran dari suatu permasalahan yang ada.

Observasi dilakukan dengan cara terjun langsung ke lapangan, pada tempat dimana permasalahan tersebut terjadi, serta mengadakan kontak langsung dengan berbagai pihak yang terkait dalam permasalahan tersebut.

b. Wawancara

Wawancara atau proses tanya jawab dengan seseorang yang diminta sebagai narasumber dimana keterangan dan pendapatnya mengenai suatu hal permasalahan sangat diperlukan guna kepentingan penelitian yang akan dilakukan. Wawancara dilakukan secara terstruktur ditujukan terhadap seluruh sampel penelitian ini.

c. Kajian kepustakaan

Mengumpulkan data dengan membaca buku-buku yang dapat dijadikan referensi maupun dari jurnal-jurnal ilmiah guna memperoleh teori-teori hukum yang akan dibutuhkan dalam proses penelitian ini. Tidak lupa juga menggunakan peraturan perundangan-undangan yang terkait langsung maupun tidak langsung dengan penelitian hukum sosiologis yang akan dilakukan. Aturan hukum adalah sebagai dasar pijakan dalam penelitian hukum guna menganalisis data-data yang diperoleh terkait dengan permasalahan yang diteliti agar penyelesaian terhadap suatu permasalahan yang diteliti, tidak menimbulkan permasalahan hukum yang baru. 


\section{Analisis data}

Data yang telah dikumpulkan melalui teknik observasi dan wawancara diolah dengan cara mengelompokkan dan memilah data yang didapat disajikan dalam bentuk uraian kalimat atau narasi yang jelas dan rinci. Data kepustakaan diinventaris sesuai kebutuhan referensi berupa teori atau penjelasan normatif dideskripsikan dalam bentuk narasi. Langkah selanjutnya penulis melakukan interpretasi data, menghubungkan satu data dengan data yang lainnya. Kemudian penulis menghubungkan dengan teori-teori dan ketentuan hukum yang berkaitan dengan permasalahan. Teknik pengambilan kesimpulan dilakukan dengan cara deduktif, yaitu metode penarikan kesimpulan dari dalil atau pernyataan yang bersifat umum ke pernyataan atau dalil yang bersifat khusus.

\section{Pembahasan}

\section{Pendirian Badan Hukum UED/K-SP di Kecamatan Bengkalis}

Badan hukum UED/K-SP menurut peraturan terkait haruslah berbadan hukum. Penegasan kembali dari pembahasan sebelumnya bahwa UED-SP berdasarkan Pasal 39 ayat (1) Undang-Undang Nomor 1 Tahun 2013 tentang LKM dapat dikategorikan sebagai LKM. LKM haruslah berbentuk badan hukum sesuai amanat Pasal 4 huruf a Undang-Undang Nomor 1 Tahun 2013 dalam bentuk koperasi atau Perseroan Terbatas/PT sahamnya paling sedikit 60 persen dimiliki oleh pemerintah daerah kabupaten/kota atau badan usaha milik desa/kelurahan, sisa kepemilikan saham PT dapat dimiliki oleh WNI atau koperasi dengan kepemilikan WNI paling banyak sebesar 20 persen sebagaimana ditentukan pada ketentuan Pasal 5 ayat (1) Undang-Undang Nomor 1 Tahun 2013.

Kemudian peraturan terkait lainnya UED-SP sebagai salah satu BUMDesa juga diatur dalam Pasal 8 Permendes PDTT Nomor 4 Tahun 2015 tentang Pendirian, Pengurusan dan Pengelolaan dan Pembubaran BUMDesa, dengan norma "BUMDesa dapat membentuk unit usaha meliputi:

a. Perseroan Terbatas sebagai persekutuan modal, dibentuk berdasarkan perjanjian, dan melakukan kegiatan usaha dengan modal yang sebagian besar dimiliki oleh BUMDesa, sesuai dengan peraturan perundang-undangan tentang Perseroan Terbatas; dan

b. Lembaga Keuangan Mikro dengan andil BUMDesa sebesar 60 (enam puluh) persen, sesuai dengan peraturan perundangundangan tentang lembaga keuangan mikro.

Secara dogmatis tegaslah BUMDesa yang menjalankan UED/K-SP harus mendirikan badan hukum sesuai amanat hukum yang berlaku. Selanjutnya dalam bab ini akan menganalisis status badan hukum UED/K-SP di Kecamatan Bengkalis. Sebagaimana telah disinggung di Kecamatan Bengkalis terdapat 31 
desa/kelurahan yang sudah berstatus definitif dan telah melaksanakan UED/K-SP sejak 2011 dengan total pengucuran dana bergulir mencapai Rp 5.000.000.000,00 (lima miliar rupiah) per desa/kelurahan.

Untuk menjawab pendirian badan hukum UED/K-SP di Kecamatan Bengkalis penulis melakukan wawancara terhadap sampel yang relevan untuk menjawab hal tersebut secara berurutan mulai dari Kepala Dinas Pemberdayaan Masyarakat dan Desa (DPMD) Bengkalis, Camat Bengkalis, Kepala Desa/Kelurahan di Kecamatan Bengkalis, Ketua/Direktur BUMDesa dan Ketua UED/K-S di Kecamatan Bengkalis.

Menurut Kepala DPMD Kabupaten Bengkaliskondisi UED-SP di Kabupaten Bengkalis, khususnya juga di Kecamatan Bengkalis sudah dileburkan menjadi BUMDesa, sandaran hukumnya tetap kepada mengacu pada UndangUndang Desa dan peraturan yang keterkaitan dengan hal ini, sementara untuk kelurahan, sampai saat ini akan dicari regulasi yang lain, karena terpisah dengan Undang-Undang Desa.

Status UED/K-SP di Kecamatan Bengkalis pada esensinya belum ada yang berbadan hukum. Hal ini dapat dipahami dari keterangan Kepala DPMD Kabupaten Bengkalis, yang mengatakan saat ini yang dilakukan baru sebatas melakukan menginventarisasi aset-aset UED-SP, setelah jelas aset-aset akan ditingkatkan menjadi BUMDesa. ${ }^{8}$ Hal yang sama juga dikatakan Camat Bengkalis yang menjelaskan "Seingat saya UED-SP di Kecamatan Bengkalis sudah dimulai tahun 2011 sejak berlakunya Undang-Undang Nomor 6 Tahun 2014 tentang Desa, diamanahkan BUMDesa sudah ditindak lanjuti dengan Peraturan Bupati Bengkalis Nomor 71 Tahun 2017". 9

Penjelasan Kepala DPMD Kabupaten Bengkalis dan Camat Bengkalis tersebut sama sekali tidak ada relevansinya dengan pendirian badan hukum UEDSP. Kemudian terkait pertanyaan pendirian badan hukum UED-SP penulis kembali menggali informasi dari Kepala Desa di Kecamatan Bengkalis.

Berdasarkan hasil wawancara Kepala Desa Senggo menjelaskan "saat ini, mengacu Peraturan Bupati Bengkalis Nomor 71 Tahun 2017 di mana UED-SP melebur menjadi BUMDesa. Hari ini sudah dibahas tentang aset, melalui USP Desa Senggoro yang dilaksanakan BUMDesa". ${ }^{10}$ Kepala Desa Wonosari mengemukakan "saat ini sudah memiliki BUMDesa bernama BUMDesa Unggul Sari, telah memiliki beberapa unit usaha di bawah naungan BUMDesa, salah satunya Unit Usaha Simpan Pinjam (USP) Mekar Sari. Dalam perjalanannya dana

\footnotetext{
${ }^{8}$ Wawancara dengan Drs. Yuhelmi selaku Kepala Dinas Pemberdayaan Masyarakat dan Desa Kabupaten Bengkalis pada tanggal 6 Agustus 2019.

${ }^{9}$ Wawancara dengan Ade Suwirman, S.STP, MAP selaku Camat Bengkalis pada tanggal 9 Juli 2019.

${ }^{10}$ Wawancara dengan Basrah Hamid selaku Kepala Desa Senggoro pada tanggal 10 Agustus 2019.
} 
bergulir telah mencapai 1.000 lebih pemanfaat dana USP Mekar Sari yang dulu bernama UED-SP". ${ }^{11}$

Kepala Desa Penebal berpendapat "Di Desa Penebal, UED-SP sebelum menjadi unit usaha simpan pinjam, dulu menjadi USP. Jadi, setelah ada ada BUMDesa maka bergabung di BUMDesa dan menjadi cabang usaha BUMDesa. Kalau dulunya UED-SP berdiri sendiri, namun sekarang sudah menjadi bagian dari USP. Jadi, untuk pelaksanaan tetap mengacu kepada aturan dan peraturan yang telah ada, untuk perkembangan saat ini". ${ }^{12}$

Kemudian Kepala Desa Pedekik yang diwakili oleh Sekretaris Desa menjelaskan "Kalau pendirian UED-SP sebelumnya berdiri sendiri, aturan yang mengaturnya sudah ada. Namun, sejak 2018 UED-SP ini sudah melebur ke BUMDesa, jadi segala sesuatu administrasi yang berkaitan dengan unit usaha, itu Surat Keputusannya ditandatangani oleh BUMDesa”. ${ }^{13}$

Terakhir Kepala Desa Air Putih tidak bersedia diwawancarai tanpa alasan yang jelas. Dari jawaban para kepala desa yang menjadi sampel penelitian ini, hasilnya juga tidak memberikan jawaban yang relevan dengan pendirian badan hukum UED-SP. Selanjutnya, agar semakin memperjelas penulis juga melakukan wawancara dengan Ketua/Direktur BUMDesa dan Ketua UED/K-S di Kecamatan Bengkalis tentang pendirian badan hukum UED-SP.

Hasil wawancara dengan Ketua USP Karya Bathin Bersama Desa Penebal petikannya sebagai berikut. ${ }^{14}$

Seiring dengan aturan hukum di atas, maka program UED/K-SP di Kecamatan Bengkalis, Kabupaten Bengkalis beroperasi sejak tahun 2011. Tepatnya, berdasarkan Surat Keputusan (SK) Bupati Bengkalis Nomor: 12/KPTS/2011 tentang Pembentukan UED-SP berangsur berganti nama menjadi Unit Simpan Pinjam (USP). Keberadaan USP ini didapat dari keterangan pengelolanya. Karena, pemerintah desa memandang perlu, jika USP menjadi salah satu unit usaha di BUMDesa. Peleburan UED/K-SP menjadi USP ini satu-satunya baru dilaksanakan di Desa Penebal. Proses peleburan, telah melakukan dua kali pencairan dana. Sehingga, dirasakan oleh pengelola USP proses pembentukannya terlalu panjang. Kemudian adanya aturan Peraturan Desa (Perdes) baru berkaitan dengan peralihan dan inventarisasi aset. Perdes terbit pada tanggal 14 Agustus 2018. Perdes itu seakan menimbulkan kegalauan dari pengelola BUMDesa dan USP serta

\footnotetext{
${ }^{11}$ Wawancara dengan Suswanto selaku Kepala Desa Wonosari pada tanggal 30 Juli 2019.

${ }^{12}$ Wawancara dengan Muhammad Saimin selaku Kepala Desa Penebal pada tanggal 5 Juni 2019.

${ }^{13}$ Wawancara dengan Maskur, SH selaku Sekretaris Desa Pedekik pada tanggal 7 Juni 2019.

${ }^{14}$ Wawancara dengan Muhadi, SAB selaku Ketua USP Karya Bathin Bersama Desa Penebal pada tanggal 4 Juni 2019.
} 
kepala desa. Sehingga, terdapat banyak desa yang belum menuntaskan penyusunan BUMDesa. Khusus Desa Penebal, melalui BUMDesa yang memiliki USP Karya Bathin Bersama melakukan koordinasi dengan DPMD Kabupaten Bengkalis. Kemudian, DPMD mengeluarkan regulasi bergaitan dengan BUMDesa. Dari BUMDesa tersebut, keluar rekomendasi dari kecamatan untuk proses peleburan dari UED-K/SP menjadi USP. Peleburan ini tentu menjadi angin segar bagi UED-K/SP. Namun, peleburan ternyata menyisakan permasalahan berkaitan dengan inventarisasi aset.

Hasil wawancara dengan Ketua USP Panglima Minal Desa Air Putih keterangannya sebagai berikut. ${ }^{15}$

Berdasarkan Perbup Nomor 52 Tahun 2011, USP Panglima Minal, Desa Air Putih, memperoleh dana usaha DUD sebesar Rp 1 miliar, di tahun 2012 mendapatkan Rp 1 miliar lagi, berikutnya 2013, 2014, 2015 sebanyak lima penganggaran, berarti dana dari Bupati sebanyak Rp 5 miliar, yang diberikan kepada USP, sampai hari ini dari 2011 sampai 2019 dana yang sudah bergulir dari Rp 5 miliar itu, sebesar Rp 15,936.300 miliar, dan pemanfaat sebanyak 1.119 pemanfaat, dari awal sampai sekarang.

Pendapat Ketua USP Desa Pedekik Agus Supeno dari hasil wawancara sebagai berikut. ${ }^{16}$

Seiring dengan aturan hukum di atas, maka program UED/K-SP di Kecamatan Bengkalis, Kabupaten Bengkalis beroperasi sejak tahun 2011. Tepatnya berdasarkan SK Bupati Bengkalis Nomor: 12/KPTS/2011 tentang Pembentukan UED-SP berangsur berganti nama menjadi USP. Saat ini, USP Desa Pedekik dana yang bergulir mencapai Rp 13,8 miliar. Dengan jumlah pemanfaat atau nasabah sebanyak 1.185 pemanfaat. Realisasi kegiatan UED-SP yang telah melebur menjadi BUMDesa tersebut sedikit mengalami kendala dilapangan.

Terakhir Ketua USP Desa Wonosari tak mau diwawancarai tanpa alasan yang rasional, sedangkan sampel lainnya, yaitu Ketua USP Desa Senggoro tak mau diwawancarai melimpahkan kepada kepala desa.

Selanjutnya, untuk mengetahui pendirian badan hukum UED-SP penulis juga melakukan wawancara dengan para Direktur BUMDesa di Kecamatan Bengkalis yang menjadi sampel terpilih. Dari 5 orang sampel yang terpilih, ada 3

${ }^{15}$ Wawancara dengan Rahmah, Amd selaku Ketua USP Panglima Minal Desa Air Putih pada tanggal 4 Juni 2019.

${ }^{16}$ Wawancara dengan Agus Supeno selaku Ketua USP Desa Pedekik pada tanggal 4 Juni 2019. 
orang yang menolak untuk diwawancarai tanpa alasan yang rasional. Adapun yang menolak diwawancarai, yaitu Direktur BUMDesa Wonosari, Direktur BUMDesa Senggoro, dan Direktur BUMDesa Pedekik.

Hasil wawancara dengan Direktur BUMDesa Karya Bhatin Bersama Desa Penebal sebagai berikut. ${ }^{17}$

Untuk badan hukum BUMDesa di Kecamatan Bengkalis ini terbilang masih baru. BUMDesa menjadi induk badan hukum dari unit-unit usaha desa. Termasuk UED-SP yang sejatinya menjalankan visi dan misinya. Dari 28 desa di Kecamatan Bengkalis, keseluruhannya sudah memiliki BUMDesa. Namun, khusus di tiga kelurahan di Kecamatan Bengkalis, sampai hari ini masih diperbincangkan terkait badan hukum untuk UED/K-SP yang sudah sempat berjalan. Sejumlah desa saat ini, juga tengah membentuk regulasi dan payung hukum yang jelas di desa, termasuk membentuk Perdes Pengalihan Aset UED/KSP sebelum adanya BUMDesa. Kemudian, membentuk unit-unit usaha lainnya sesuai dengan potensi di desa. Peran BUMDesa di desa sebagai fungsi pengawasan dan menerima laporan dari unit-unit usaha serta kelembagaan masyarakat.

Kemudian menurut Direktur BUMDesa Air Putih Jaya: ${ }^{18}$

Kenapa BUMDesa ini hadir di desa, bahwasanya BUMDesa merupakan amanah Undang-Undang Nomor 6 Tahun 2014 tentang Desa. Dalam hal ini kehadiran BUMDesa di desa, salah satunya menunjang perekonomian masyarakat setempat. BUMDesa, salah satunya di Desa Air Putih sudah ada USP sejak 2012.

Memperhatikan informasi yang didapat dari hasil wawancara dengan Ketua/Direktur BUMDesa dan Ketua UED/K-S di Kecamatan Bengkalis tentang pendirian badan hukum UED-SP, penulis dapat menarik benang merah bahwa berdasarkan keterangan yang didapat pada esensinya tidak menjelaskan pendirian badan hukum UED-SP. Substansi yang disampaikan, bahwa UED-SP melebur menjadi USP yang merupakan bagian dari usaha milik BUMDesa. Sementara, USP sendiri bukanlah badan hukum yang dimaksud Pasal 39 ayat (1) UndangUndang Nomor 1 Tahun 2013 tentang LKM dapat dikategorikan sebagai LKM. Di mana LKM haruslah berbentuk badan hukum sesuai amanat Pasal 4 huruf a Undang-Undang Nomor 1 Tahun 2013 dalam bentuk koperasi atau PT sahamnya paling sedikit 60 persen dimiliki oleh pemerintah daerah kabupaten/kota atau badan usaha milik desa/kelurahan. Kemudian peraturan terkait lainnya UED-SP

${ }^{17}$ Wawancara dengan Abadi, Amd selaku Direktur BUMDesa Karya Bhatin Bersama Desa Penebal pada tanggal 15 Juni 2019.

${ }^{18}$ Wawancara dengan Indo Marlinton selaku Direktur BUMDesa Air Putih Jaya Indopada tanggal 16 Juni 2019. 
sebagai salah satu BUMDesa juga diatur dalam Pasal 8 Permendes PDTT Nomor 4 Tahun 2015 tentang Pendirian, Pengurusan dan Pengelolaan dan Pembubaran BUMDesa, dengan norma "BUMDesa dapat membentuk unit usaha PT atau koperasi. Dengan demikian, tidak ada satupun UED-SP di Kecamatan Bengkalis yang sudah memenuhi persyaratan LKM dan berbadan hukum sesuai ketentuan Pasal 4 huruf a Undang-Undang Nomor 1 Tahun 2013 jo Pasal 8 Permendes PDTT Nomor 4 Tahun 2015.

\section{Hambatan Pendirian Badan Hukum UED/K-SP di Kecamatan Bengkalis}

Sebagaimana telah disinggung dalam pembahasan sebelumnya bahwa tidak ada satupun UED-SP di Kecamatan Bengkalis yang sudah memenuhi persyaratan LKM dan berbadan hukum sesuai ketentuan Pasal 4 huruf a Undang-Undang Nomor 1 Tahun 2013 jo Pasal 8 Permendes PDTT Nomor 4 Tahun 2015. Untuk itu, perlu dikemukakan hambatan pendirian badan hukum tersebut. Guna menjelaskan tentang hambatan dimaksud penulis kembali melakukan wawancara dengan sampel terpilih untuk menjawab hal tersebut secara berurutan mulai dari Kepala Dinas Pemberdayaan Masyarakat dan Desa (DPMD) Bengkalis, Camat Bengkalis, Kepala Desa/Kelurahan di Kecamatan Bengkalis, Ketua/Direktur BUMDesa dan Ketua UED/K-S di Kecamatan Bengkalis.

Kepala DPMD Kabupaten Bengkalis mengemukakan "Hambatan pendirian badan hukum UED-SP berkaitan dengan inventarisasi aset UED-SP, setelah jelas aset maka akan ditingkatkan menjadi BUMDesa". ${ }^{19}$ Camat Bengkalis berpendapat "Ada 2 (dua) hambatan: Pertama, pengelolanya sendiri, perlu saya sampai juga, sudah banyak pengelola UED-SP ini yang sudah berurusan dengan hukum. Kedua, masyarakat sebagai pemanfaat UED-SP ada yang beranggapan dana UED-SP adalah dana hibah, sehingga dananya tidak bergulir, padahal masih banyak masyarakat-masyarakat lain yang ingin berusaha dan meminjam, tapi karena banyaknya tunggakan maka tidak bisa dicairkan lagi pada tahap berikutnya". ${ }^{20}$

Bila dianalisis jawaban Kepala DPMD Kabupaten Bengkalis dan Camat Bengkalis, jawaban yang ada relevansinya dengan hambatan pendirian badan hukum UED-SP, yaitu tentang inventarisasi aset. Hambatan lainnya, yaitu pengelolaan dan macetnya pengembalian pinjaman, tidak ada relevansinya dengan hambatan pendirian badan hukum UED-SP.

Selanjutnya, penulis melakukan wawancara dengan Kepala Desa yang menjadi sampel terpilih untuk menjelas pendapatnya berkaitan dengan hambatan pendirian badan hukum UED-SP. Kepala Desa Senggoro mengemukakan

\footnotetext{
${ }^{19}$ Wawancara dengan Drs. Yuhelmi selaku Kepala Dinas Pemberdayaan Masyarakat dan Desa (DPMD) Kabupaten Bengkalis pada tanggal 6 Agustus 2019.

${ }^{20}$ Wawancara dengan Ade Suwirman selaku Camat Bengkalis pada tanggal 29 Juli 2019. 
"Hambatan pelaksanaan belum begitu lancar, dikarenakan masih ada tunggakan". ${ }^{21}$ Hal yang sama dikatakan Kepala Desa Wonosari "Kendala yang sering timbul, yang disebabkan terkadang macetnya pengembalian dari masyarakat". 22 Pendapat berbeda dikemukakan Kepala Desa Penebal yang mengatakan "Kalau masalah hambatan, saya rasa sudah tidak ada hambatan". ${ }^{23}$ Kepala Desa Pedekik diwakili Sekretaris Desa mengemukakan "UED-SP itu harus berbadan hukum, PT atau koperasi belum ada petunjuknya. Perbup berkaitan peleburan ke BUMDesa, kita menyiapkan apa yang menjadi ketentuan, seperti Perdes. Tanpa ada Perdes tidak bisa dicairkan, baik USP dan BUMDesa jelas menjadi keuangan mikro, keuangan mikro bisa jadi juga arah ke sana. Lembaga ini sebagai penguatan ekonomi masyarakat". ${ }^{24}$ Sampel Kepala Desa Air Putih tidak bersedia memberikan memberikan informasi tanpa alasan yang jelas.

Selanjutnya penulis mewancarai Ketua USP dan Direktur BUMDesa yang menjadi sampel terpilih berkaitan dengan hambatan pendirian badan hukum UEDSP. Ketua USP Karya Bathin Bersama Desa Penebal menjelaskan USP Karya Bathin Bersama sebagai LKM di bawah BUMDesa ini sudah saatnya terdaftar di OJK sesuai dengan Undang-Undang Nomor 1 Tahun 2013 tentang LKM. Latar belakang Undang-Undang Nomor 1 Tahun 2013 tentang LKM, kerap menjadi masukan dan saran dibeberapa kali diskusi serta forum rapat. Artinya, USP melakukan peleburan karena sebuah keharusan". ${ }^{25}$ Ketua USP Panglima Minal Desa Air Putih mengemukakan "Hambatan dilapangan, kadang pemanfaat lancar bayar kadang tidak". ${ }^{26}$ Pendapat Ketua USP Desa Pedekik "Pada tahun 2019 lalu, terjadi penunggakan sebesar Rp1 miliar lebih. Untuk menyiasatinya, USP melayangkan surat kepada pemanfaat yang nunggak tagihan atas pinjaman”. ${ }^{27}$ Kemudian sampel lainnya, yaitu Ketua USP Desa Wonosari tak mau diwawancarai, begitu juga Ketua USP Desa Senggoro tak mau diwawancarai justru melimpahkan kepada kepala desa.

Selanjutnya terkait hambatan pendirian badan hukum UED-SP penulis juga mewancarai Direktur BUMDesa yang menjadi sampel terpilih. Tetapi,

\footnotetext{
${ }^{21}$ Wawancara dengan Basrah Hamid selaku Kepala Desa Senggoro pada tanggal 10 Agustus 2019.

${ }^{22}$ Wawancara dengan Suswanto selaku Kepala Desa Wonosari pada tanggal 30 Juli 2019.

${ }^{23}$ Wawancara dengan Muhammad Saimin selaku Kepala Desa Penebal pada tanggal 4 Juni 2019.

${ }^{24}$ Wawancara dengan Maskur, SH selaku Sekretaris Desa Pedekik pada tanggal 7 Juni 2019.

${ }^{25}$ Wawancara dengan Muhadi, SAB selaku Ketua USP Karya Bathin Bersama Desa Penebal pada tanggal 4 Juni 2019.

${ }^{26}$ Wawancara dengan Rahmah, Amd selaku Ketua USP Panglima Minal Desa Air Putih pada tanggal 4 Juni 2019.

${ }^{27}$ Wawancara dengan Agus Supeno selaku Ketua USP Desa Pedekik pada tanggal 4 Juni 2019.
} 
sebagaimana telah disinggung dari 5 orang sampel yang terpilih, ada 3 orang yang menolak untuk diwawancarai tanpa alasan yang rasional. Adapun yang menolak diwawancarai, yaitu Direktur BUMDesa Wonosari, Direktur BUMDesa Senggoro, dan Direktur BUMDesa Pedekik.

Direktur BUMDesa yang bersedia diwawancarai memberikan, seperti Direktur BUMDesa Karya Bhatin Bersama Desa Penebal berpendapat "Hambatan masih belum ada. Paling mengenai peralihan aset yang hari ini sudah tuntas dibahas melalui Perdes, sehingga BUMDesa melakukan langkah menyusun pengurus BUMDesa terdiri dari, Komisaris, Direktur, dan Pengawas. Komisaris langsung dijabat oleh kepala desa, sedangkan jabatan direktur serta pengawasan berasal dari independen dipilih melalui musyawarah desa bersama dengan Badan Pemusyawaratan Desa (BPD) mengikutsertakan para pendamping desa". ${ }^{28}$

Kemudian Direktur BUMDesa Air Putih Jaya mengemukakan "BUMDesa ini mengacu pada modal berdasarkan Perbup Nomor 71 Tahun 2014 bahwasanya penyertaan modal itu kembalinya kepada BUMDesa. Artinya, apabila modal tak kembali maka akan diserahkan kepada proses hukum". ${ }^{29}$

Berdasarkan hasil wawancara khususnya terhadap kepala desa, Ketua USP dan Direktur BUMDesa di atas tidak memberikan jawaban yang berkaitan dengan pendirian badan hukum UED-SP. Jawaban yang sedikit relevan hanyalah terkait peralihan aset, sedangkan jawaban selebihnya berkaitan dengan macetnya pengembalian pinjaman. Artinya, lain yang ditanya, lain pula yang dijawab.

\section{Upaya Mengatasi Hambatan Pendirian Badan Hukum UED/K-SP di Kecamatan Bengkalis}

Pembahasan sebelumnya telah diketahui bahwa hambatan yang relevan hanyalah terkait peralihan aset. Selanjutnya, terkait hambatan pendirian badan hukum UED/K-SP di Kecamatan Bengkalis penulis kembali melakukan wawancara dengan sampel terpilih untuk menjawab hal tersebut secara berurutan mulai dari Kepala Dinas Pemberdayaan Masyarakat dan Desa (DPMD) Bengkalis, Camat Bengkalis, Kepala Desa/Kelurahan di Kecamatan Bengkalis, Ketua/Direktur BUMDesa dan Ketua UED/K-S di Kecamatan Bengkalis.

Kepala DPMD Kabupaten Bengkalis, "Upaya yang dilakukan adalah pembinaan dan pengawasan, serta memberdayakan tenaga pendamping desa bidang ekonomi. ${ }^{30}$ Kemudian menurut Camat Bengkalis "Upaya pelatihan

\footnotetext{
${ }^{28}$ Wawancara dengan Abadi, Amd selaku Direktur BUMDesa Karya Bhatin Bersama Desa Penebal pada tanggal 15 Juni 2019.

${ }^{29}$ Wawancara dengan Indo Marlinton selaku Direktur BUMDesa Air Putih Jaya pada tanggal 16 Juni 2019.

${ }^{30}$ Wawancara dengan Drs. Yuhelmi selaku Kepala Dinas Pemberdayaan Masyarakat dan Desa (DPMD) Kabupaten Bengkalis pada tanggal 6 Agustus 2019.
} 
BUMDesa dan UED-SP setiap tahun rutin dilaksanakan DPMD. Berkaitan dengan LKM, kurang paham. Jadi, ada baiknya ditanya kepada DPMD Bengkalis". ${ }^{31}$

Jika dianalisis jawaban Kepala DPMD Kabupaten Bengkalis dan Camat Bengkalis tersebut tidak ada hubungannya dengan kendala yang telah dikemukakan sebelumnya, yaitu terkait peralihan aset. Camat Bengkalis sendiri mengakui tidak memahami tentang LKM. Selanjutnya penulis melakukan wawancara terhadap kepala desa, yang substansinya untuk mendapatkan informasi tentang upaya mengatasi kendala pendirian badan hukum UED-SP.

Menurut Kepala Desa Senggoro mengatakan "Sudah melakukan upaya monitoring melalui rapat, tentang permasalahan perjalanan tentang UED-SP". ${ }^{32}$ Kepala Desa Wonosari mengemukakan "kekurangan atau minimnya modal dengan konsekuensi pertanggungjawaban benar-benar untuk meningkatkan permodalan usaha masyarakat tersebut". ${ }^{33}$ Kepala Desa Penebal menjelaskan "Sebagai LKM, jelasnya menggunakan dana transfer, mau tidak mau harus mengikuti aturan yang berlaku. Setiap peminjam itu harus memenuhi syarat, selain itu juga survei dari pengelola". ${ }^{34}$ Kepala Desa Pedekik yang diwakili Sekretaris Desa mengemukakan "Upayanya melalui monitoring, harapannya BUMDesa bisa membentuk unit yang menjadi potensi, dan menggali potensi desa. Diharapkan BUMDesa ini bisa menciptakan lapangan pekerjaan. ${ }^{35}$ Khusus Kepala Desa Air Putih menolak untuk diwawancara tanpa alasan yang jelas.

Selanjutnya penulis uraikan hasil wawancara dengan Ketua USP dan Direktur BUMDesa yang menjadi sampel penelitian ini untuk mendapatkan informasi tentang upaya mengatasi kendala pendirian badan hukum UED-SP. Menurut Ketua USP Karya Bathin Bersama Desa Penebal "Di samping nilai keuntungan, USP sering dihadapkan dengan persoalan nasabah nunggak bayar. Untuk USP Karya Bathin Bersama, tentang pinjaman ke masyarakat tetap mengedepankan sifat pemberdayaan masyarakat dan mengkesampingkan pola ekstrim, seperti perbankan, lembaga pembiayaan konsumen ataupun koperasi". ${ }^{36}$

Ketua USP Panglima Minal Desa Air Putih menjelaskan "Bila ada tunggakan maka diberi surat peringatan (SP). Jika tidak juga membayar, sampai

\footnotetext{
${ }^{31}$ Wawancara dengan Ade Suwirman, S.STP, MAP selaku Camat Bengkalis pada tanggal 29 Juli 2019.

${ }^{32}$ Wawancara dengan Basrah Hamid selaku Kepala Desa Senggoro pada tanggal 10 Agustus 2019.

${ }^{33}$ Wawancara dengan Suswanto selaku Kepala Desa Wonosari pada tanggal 30 Juli 2019.

${ }^{34}$ Wawancara dengan Muhammad Saimin selaku Kepala Desa Penebal pada tanggal 4 Juni 2019.

${ }^{35}$ Wawancara dengan Maskur, SH selaku Sekretaris Desa Pedekik pada tanggal 7 Juni 2019.

${ }^{36}$ Wawancara dengan Muhadi, SAB selaku Ketua USP Karya Bathin Bersama Desa Penebal pada tanggal 4 Juni 2019.
} 
dengan SP-2, maka diberikan arahan agar membayar cicilan". ${ }^{37}$ Ketua USP Desa Pedekik berpendapat "Sejak UED-SP menjadi bagian unit usaha dari BUMDes, maka sejak itu pula segala ketentuan yang berlaku dalam administrasi diperkuat. Karena, nantinya akan dibentuk badan hukum perkoperasian yang sudah disepakati bersama. Aturan dan ketentuan badan hukum itu sudah jelas. Untuk desa itu nantinya koperasi. Untuk sementara ini kami masih menunggu petunjuk dari pemerintah daerah dalam hal ini DPMD Bengkalis dan Bupati". ${ }^{38}$ Selanjutnya, Ketua USP Desa Wonosari dan Ketua USP Desa Senggoro tidak memberikan informasi karena tidak bersedia diwawancarai.

Kemudian pada bagian akhir penulis kembali melakukan wawancara dengan Direktur BUMDesa yang terpilih menjadi sampel penelitian ini untuk mendapatkan informasi yang sama, yaitu tentang upaya mengatasi kendala pendirian badan hukum UED-SP.

Direktur BUMDesa Karya Bhatin Bersama Desa Penebal mengemukakan "Jika hari ini USP menjadi unit usaha di bawah naungan BUMDesa, maka BUMDesa terus melakukan pengawasan dan evaluasi terhadap unit usaha tersebut". ${ }^{39}$ Direktur BUMDesa Air Putih Jaya menjelaskan "Hambatan belum ada, karena sampai saat ini USP masih belum duduk persoalan pengalihan aset". ${ }^{40}$

Selanjutnya, Direktur BUMDesa Wonosari, Direktur BUMDesa Senggoro, dan Direktur BUMDesa Pedekik menolak untuk diwawancarai tanpa alasan yang rasional. Berdasarkan keterangan yang diberikan oleh Kepala Desa, Ketua USP dan Direktur BUMDesa Kecamatan Bengkalis yang menjadi sampel ini maka tidak ada hubungannya dengan kendala yang telah dikemukakan sebelumnya, yaitu terkait peralihan aset.

\section{Penutup}

\section{Kesimpulan}

1. Pendirian badan hukum UED/K-SP di Kecamatan Bengkalis haruslah berbentuk badan hukum sesuai amanat Pasal 4 huruf a Undang-Undang Nomor 1 Tahun 2013 jo Pasal 8 Permendes PDTT Nomor 4 Tahun 2015. Hasil penelitian ini dapat diketahui tidak ada satupun UED-SP di Kecamatan Bengkalis yang sudah memenuhi persyaratan LKM dan berbadan hukum.

\footnotetext{
${ }^{37}$ Wawancara dengan Rahmah, Amd selaku Ketua USP Panglima Minal Desa Air Putih pada tanggal 4 Juni 2019.

${ }^{38}$ Wawancara dengan Agus Supeno selaku Ketua USP Desa Pedekik pada tanggal 4 Juni 2019.

${ }^{39}$ Wawancara dengan Direktur BUMDesa Karya Bhatin Bersama Desa Penebal, Abadi, Amd pada tanggal 15 Juni 2019.

${ }^{40}$ Wawancara dengan Indo Marlinton selaku Direktur BUMDesa Air Putih Jaya Indo pada tanggal 6 Juni 2019.
} 
2. Hambatan pendirian badan hukum UED/K-SP di Kecamatan Bengkalis dari hasil penelitian ini jawaban yang relevan hanyalah terkait peralihan aset, sedangkan jawaban selebihnya dari sampel penelitian tidak ada relevansinya dengan hambatan pendirian badan hukum UED/K-SP.

3. Upaya mengatasi hambatan pendirian badan hukum UED/K-SP di Kecamatan Bengkalis tidak ada rencana dan tindakan konkrit untuk mengatasi hambatan dimaksud. Hal ini disebabkan karena seluruh sampel penelitian ini seluruhnya tidak memahami pendirian badan hukum UED/KSP.

\section{Saran}

1. Agar UED/K-SP di Kecamatan Bengkalis berbadan badan hukum maka sebaiknya seluruh pihak terkait memahami amanat Pasal 4 huruf a UndangUndang Nomor 1 Tahun 2013 jo Pasal 8 Permendes PDTT Nomor 4 Tahun 2015 dan langkah-langkah pendirian badan hukum tersebut.

2. Agar hambatan pendirian badan hukum UED/K-SP di Kecamatan Bengkalis dari hasil penelitian ini jawaban terkait peralihan aset, maka sebaiknya pihak terkait melaksanakan peralihan aset sesuai prosedur hukum yang berlaku di Kabupaten Bengkalis, yaitu Perbub No. 71 Tahun 2017 tentang Penyertaan Modal Desa ke Badan Usaha Milik Desa Dari Dana Ekonomi Desa.

3. Agar semua pihak terkait dapat memahami pendirian badan hukum UED/KSP maka sebaiknya diberikan pelatihan atau workshop secara khusus dilaksanakan untuk kebutuhan tersebut.

\section{Daftar Pustaka}

Budi Hartono, Perlindungan Debitur KPM \& KPR Menghadapi Penagihan Hutang dan Lelang Jaminan oleh Kreditur, Jakarta: PT Pustaka Utama Grafiti, 2009.

Rahmi Puspita Sari, Rosnita, dan Ahmad Rifai, Analisis Kinerja Sosial dan Kinerja Keuangan Lembaga Keuangan Mikro (LKM) Usaha Ekonomi Desa-Simpan Pinjam (UED-SP) Badan Usaha Milik Desa (BUMDes) Mekar Jaya Desa Bukit Sembilan Kecamatan Bangkinang Kabupaten Kampar, Jurnal Online Mahasiswa, Fakultas Pertanian Universitas Riau, Vol. 1, No. 2 Oktober 2019.

Galih Delia, Implementasi Kebijakan Pengembangan UED-SP Menjadi Bumdes di Kabupaten Rokan Hulu (Studi Kasus Bumdes Mekar Sari Desa Rambah Baru Kecamatan Rambah Samo), Jurnal Online Mahasiswa 
Fakultas Ilmu Sosial dan Politik Universitas Riau, Vol. 5, Edisi I Januari-Juni 2018.

Peter Mahmud Marzuki, Penelitian Hukum, Jakarta: Kencana, 2009.

Soerjono Soekanto, Pengantar Penelitian Hukum, Jakarta: UI Press, 1986.

Yulia Risa, Engrina Fauzi dan Jelisye Putri Cenery, Peranan Pendirian Badan Usaha Milik Nagari Berdasarkan Undang-Undang Nomor 6 Tahun 2014 tentang Desa dalam Upaya Peningkatan Ekonomi Masyarakat di Nagari Cupak Kecamatan Gunung Talang Kabupaten Solok, Jurnal Ius Constituendum, Vol. 4 No. 2, Oktober 2019.

Undang-Undang Nomor 1 Tahun 2013 tentang Lembaga Keuangan Mikro (LKM).

Peraturan Menteri Dalam Negeri (Permendagri) Nomor 6 Tahun 1998 tentang UED/K-SP.

Perturan Daerah Kabupaten Bengkalis Nomor 1 Tahun 2014 tentang Tata Cara Pembentukan dan Pengelolaan Badan Usaha Milik Desa. 